The Road to Interdisciplinarity 


\title{
Toward an Anthropology of the Road
}

\author{
Dimitris Dalakoglou \\ Vrije University Amsterdam
}

The cross-pollination made possible by bringing critical studies of mobility from different disciplines into conversation with one another is a goal of $\mathrm{T}^{2} \mathrm{M}$ and Mobility in History generally, and this special section on roadways in history and anthropology specifically. Anthropologists and historians of mobility, roads, and automobility have a great deal to share with one another and with our colleagues in other disciplines. As an anthropologist, a representative of a still relatively new discipline in the pages of Mobility in History, I've been invited to open this section with a review of how my discipline has approached the subject of roads.

It is my hope that this review will mesh with the excellent works of my historian, geographer, and sociologist colleagues who have offered similar reviews from the vantage point of their disciplines in these pages in past yearbooks. Moreover, it intends to set the stage for the reviews highlighted in this section. Anthropologist Amiel Bize offers a review focused on how anthropologists have understood roadways in Africa. Historian Michael Bess shares a piece about the ways historians have grappled with similar topics in Latin America. Anthropologist Cheryl Croshere comments on how expertise shapes roadways. Historian Georgine Clarsen reflects on how automobiles formed a crucial part of first settler and then Aboriginal identities in Australia. Together, these pieces offer an interdisciplinary look at the ways mobility scholars are thinking about roads and automobility.

\section{Roads and Anthropologists}

Traditionally, most anthropological work has been devoted to studying populations portrayed as antithetical to the dominant trends in modern and capitalist society. Highways and automobility were considered Western and modern ele-

I would like to thank Penny Harvey, Kyle Shelton, Setha Low, and Michael Herzfeld for discussing on different occasions the content of this text. 
ments, far from the ethnographic Other, presenting a complicated subject for anthropologists. The widespread introduction of roads on a global level across the twentieth century sparked three distinct reactions within anthropology, which have been reflected in anthropological research on the subject: (1) an underestimation of the effect roads would have; (2) a disapproval of roads; and (3) an enthusiastic reception to the newfound ease of access provided by roads.

First, many classical disciplinary ancestors underestimated (rather ineloquently) the impact of highways on their ethnographic "objects." Most typically, Evans-Pritchard suggested that although the Azande of central Africa had changed their pattern of settlement by concentrating it around the newly constructed roads-instead of streams, as they had before-he could not in fact ascribe to roads "any great change in the life of the Azande." Highways, in the eyes of Evans-Pritchard, brought the imagined exotic a few steps nearer to the nonexotic world. Writing "a few steps nearer" was, in fact, quite literal, as it seems that his anthropological objects constituted mainly walkers rather than drivers and passengers, with a preference for barefoot walkers. Walking barefoot implied an a priori hierarchical classification of people, as Tim Ingold explains in his discussion of cultures characterized by walking versus those with a culture of vehicle mobility. ${ }^{2}$ Thus, Evans-Pritchard's subjects were indeed barefoot-and hence closer to nature. They were passive receivers of change, unaffected by highways:

I am not concerned here with those changes, which were mostly imposed on the Azande and are-when I use the present tense the reference is to the years 1926$30-$ not regarded by them as part of their way of life but something to be passively accepted or to be circumvented or ignored. To give one example: though the Administration compelled them to maintain wide roads it was noticeable that when a group of Azande walked down them they did so in single file as they were accustomed to do along their bush paths. ${ }^{3}$

Second, there was, in some respects, an unspoken competition between ethnologists to reach the most isolated and remote places, and as such the most primitive and exotic of peoples. Early anthropological accounts are full of references to isolated subjects accessed by poor quality (mostly preautomobile) roads. In 1884, Franz Boas observed that "the natives who had visited Padli in March had reported that the road was very bad; that the land was very nearly clear of snow and that the sledge would have to be carried over high rocks." ${ }^{4}$ Levi-Strauss's

1. Edward Evan Evans-Pritchard, "The Zande Corporation of Witchdoctors," Journal of the Royal Anthropological Institute of Great Britain and Ireland 62 (1932): 291-336.

2. Timothy Ingold, "Culture on the Ground: The World Perceived through the Feet," Journal of Material Culture 9, no. 3 (2004): 315-340.

3. Edward Evan Evans-Pritchard, "A Contribution to the Study of Zande Culture," Africa 30, no. 4 (1960): 31

4. Franz Boas, "A Journey in Cumberland Sound and on the West Shore of Davis Strait in 1883 and 1884," Journal of the American Geographical Society of New York 16 (1884): 265. 
early ethnographic explorations in South America were equally explicit: "I occasionally took that step on horseback with some colleagues when we came to the end of one of the few roads available at the time." ${ }^{5}$ Moreover, Edmund Leach, in an interview with Adam Kuper, recalled his first type of ethnographic excursion in China, while still a civil engineer: "Chungking itself was still a mediaeval city, all steps and sedan chairs. No roads or motor vehicles except the odd half-disintegrated bus." ${ }^{6}$ Even Paul Rabinow, a reflexive anthropologist, stated about his fieldwork that "the road for the first five miles is little more than a path-untarred, pitted, and winding and steep in places. ${ }^{7}$ Moreover, anthropologists who later focused their research on networked infrastructures, such as Caroline Humphrey, were explicit about the difficult roads in their places of research: "the road crosses a high mountain pass which is snowy even in midsummer, and plane tickets, unless booked months in advance, are obtainable only on a who-youknow basis." ${ }^{8}$ In these cases the journey to the sites of study, the difficulty of crossing nearly impassable roads, was part of their significance.

By the latter half of the twentieth century, ethnologists began to acknowledge that highways had marked the end of the semi-isolated, nonmodern people that comprised the discipline for most of its history. The improvement and spread of roadways meant the loss of unstudied subjects. Thus, given the enthusiasm for, and informal competition to reach, remote places, many anthropologists grew to regret the success of roadways. As Levi-Strauss explained, by the 1960s, roads already implied the end of isolated ethnographic subjects: "Likewise, the establishment of the new federal capital of Brazil and the building of roads and aerodromes in remote parts of South America have led to the discovery of small tribes in areas where no native life was thought to exist." ${ }^{\prime 9}$ Twenty years later, Michael Herzfeld was much more explicit on the potential sources of anthropological road phobia: highways "strangulate" the traditional practices of the ethnographic subject, in his case the customary animal theft of the Cretan villagers. ${ }^{10}$

Finally, as with all things, the arrival of better roads and better access brought new opportunities, and more positive assessments of the roads that were reaching the once-isolated ethnographic subject began to emerge:

More than anything else, the completion of the jeep road opened up the Fore region, changing it almost overnight from an isolated region to one open to free

5. Claude Levi-Strauss, "Interview: Claude Lévi-Strauss, Diacritics 1, no. 1 (1971): 45.

6. Adam Kuper, "An Interview with Edmund Leach," Current Anthropology 27, no. 4 (1986): 375.

7. Paul Rabinow, Reflections on Fieldwork in Morocco (1977; repr., Berkeley: University of California Press, 2007), 44.

8. Caroline Humphrey, "Perestroika and the Pastoralists," Anthropology Today 5, no. 3 (1989): 6.

9. Claude Lévi-Strauss, "Anthropology: Its Achievements and Future," Current Anthropology 7, no. 2 (1966): 125.

10. Michael Herzfeld, The Poetics of Manhood (Princeton, NJ: Princeton University Press, 1986), 270. 
travel and commerce and, more important, in contact with the outside world.... The power of the road is hard to overestimate. It was a great artery where only restricted capillaries had existed before, and down this artery came a flood of new goods, new ideas, new peoples, and, above all, excitement.... It was to the Fore an opening to a new world. ${ }^{11}$

Even as some begrudged the changes roads brought, others such as Sorenson began to incorporate the systems into their studies and talk to their subjects about the impacts of the new infrastructure.

\section{Toward an Anthropology of the Road}

Beginning in the 1960s anthropologists began considering the idea that infrastructure was an important element of the anthropological project. ${ }^{12}$ Such contributions were directly inspired by work on Marxist historical materialism and triggered a series of debates within the discipline on the emphasis that should be put on material formations and culture. The authors of more recent scholarship on infrastructure owe a debt to the immense value these earlier works provided. Yet, the earlier works lacked ethnographic depth, as so often happens with grand theoretical schemes. Contemporary scholars of infrastructure have embraced the idea as a central theme within the discipline and brought to it a stronger ethnographic and empirical emphasis. ${ }^{13}$

A great deal of recent work on roads and infrastructure has been conducted in African countries. This happened due to an overlap of the desire to pursue nonmainstream or Western subjects and the immense sociopolitical power of infrastructure in Africa that was constructed by colonialists for the sake of more effective exploitation of the continent's natural resources. The latter was observed ethnographically happening in real time. The foundational work of Max Gluckman in Zululand led the way for a generation of scholars focused on the subject of roads across the continent. ${ }^{14}$ In the past three decades automobility

11. Richard Sorenson, "Socio-Ecological Change among the Fore of New Guinea (and Comments and Replies)," Current Anthropology 13, nos. 3-4 (1972): 366.

12. Maurice Godelier, Maurice Bloch, Henri J. Claessen, David D. Gilmore, Oriol Pi-Sunyer, and Zoltán Tagányi, "Infrastructures, Societies, and History [and Comments]," Current Anthropology 19, no. 4 (1978): 763-771; Marvin Harris, Cultural Materialism: The Struggle for a Science of Culture (New York: AltaMira Press, 1968; repr., 2001).

13. Caroline Humphrey, "Ideology in Infrastructure: Architecture and Soviet Imagination," Journal of the Royal Anthropological Institute 11, no. 1 (2005): 39-58; Brian Larkin, "The Politics and Poetics of Infrastructure," Annual Review of Anthropology 42 (2013): 327-343; Brian Larkin, Signal and Noise: Media, Infrastructure, and Urban Culture in Nigeria (Durham, NC: Duke University Press, 2008); Dimitris Dalakoglou and Penny Harvey, "Roads and Anthropology: Ethnographic Perspectives on Space, Time and (Im)mobility," Mobilities 7, no. 4 (2012): 459-465.

14. Max Gluckman, Analysis of a Social Situation in Modern Zululand (Manchester: Manchester University Press, 1958). 
and highways in Africa have been a popular subject. Scholars have studied the subject from southern Niger ${ }^{15}$ to Zaire ${ }^{16}$; from the Central African Republic ${ }^{17}$ to Madagascar. ${ }^{18}$ Morten Nielsen has more recently explored highways in Mozambique through the lens of the road construction efforts of Chinese companies. ${ }^{19}$ In a special issue of the journal Mobilities there is an article by Gabriel Klaeger on Ghana's ethics of rushing on the highway. ${ }^{20}$ Africa as the hotspot of global development seems to attract a lot of interest, as a recently edited collection shows. ${ }^{21}$

Africa has not gotten all of the attention; one of the first monographs written by an anthropologist on a highway was Emilio Moran's work on the Transamazonian highway. ${ }^{22}$ Again, and as Levi-Strauss's statement earlier in the article reveals, that was a process observed in real time ethnographically, a process led by economic interests that aimed to most effectively exploit the region's natural resources. Yet as all ethnographic approaches to roads show, roads-built or unbuilt-have multiple layers of impact and meanings, and often sociocultural impacts beyond the anthropological or other academic imagination. The Amazonian region is also studied by Jeremy Campbell, who writes about the "not yet" effect of a road in Amazonia that has been under construction for several decades and never seems to connect. ${ }^{23}$ Highways in Latin America have also been researched extensively, especially in the case of Peru. ${ }^{24}$ Many of these scholars

15. Adeline Masquelier, "Encounter with a Road Siren: Machines, Bodies and Commodities in the Imagination of a Mawri Healer," Visual Anthropology Review 8, no. 1 (1992): 56-69; Adeline Masquelier, "Road Mythographies: Space, Mobility and the Historical Imagination in Postcolonial Niger," American Ethnologist 24, no. 4 (2002): 829-856.

16. James Fairhead, "Paths of Authority: Roads, the State and the Market in Eastern Zaire," The European Journal of Development Research 4, no. 2 (1994): 15-37.

17. Tamara Giles-Vernick, "Ne lege ti guiriri" [On the road to history], Ethnohistory 43, no. 2 (1996): 225-275.

18. Jennifer Cole, "The Work of Memory in Madagascar," American Ethnologist 25, no. 4 (1998): 610-633; Philip Thomas, "The River, the Road, and the Rural-Urban Divide: A Postcolonial Moral Geography from Southeast Madagascar," American Ethnologist 29, no. 2 (2002): 366-391.

19. Morten Nielsen, "Roadside Inventions: Making Time and Money Work at a Road Construction Site in Mozambiqu," Mobility 7, no. 4 (2012): 467-480.

20. Gabriel Klaeger, "Rush and Relax: The Rhythms and Speeds of Touting Perishable Products on a Ghanaian Roadside," Mobilities 7, no. 4 (2012).

21. Dimitris Dalakoglou and Penny Harvey, eds., Roads and Anthropology: Infrastructures, Ethnography, (Im)mobility (London: Routledge, 2014); Gabriel Klaeger, "Introduction: The Perils of the African Roads," Africa 83 (2013): 359-366.

22. Emilio Moran, Developing the Amazon: The Social and Ecological Impact of Settlement along the Transamazon Highway (Bloomington: Indiana University Press, 1981).

23. Jeremy M. Campbell, "Between the Material and the Figural Road," Mobilities 7, no. 4 (2012): 481-500.

24. Penny Harvey, "The Materiality of State Effect: An Ethnography of a Road in the Peruvian Andes," in State Formation: Anthropological Perspectives, ed. Christian Krohn-Hansen and Knut G. Nustad (London: Pluto, 2005), 216-247; Penny Harvey and Hannah Knox, "The Enchantment of Infrastructure," Mobilities 7, no. 4 (2012): 521-536; Richard Kernaghan, "Furrows and Walls," Mobilities 7, no. 4 (2012): 501-520. 
focus on how the materialities of road surface and the metaphors it carriesspeed, political integration, and economic connectivity-operate as a process of enchantment. ${ }^{25}$

As a location with a long history of both roads and automobility, European and Mediterranean scholars have also grappled with the subjects. Examples from Portugal, ${ }^{26}$ Spain,${ }^{27}$ and Palestine ${ }^{28}$ are all essential. The case of the Balkans has proven fruitful, as well as works on both Yugoslavia ${ }^{29}$ and Albania. ${ }^{30}$ In this brief list of anthropological studies of highways in Europe, we have to include work done on Sweden and Denmark by Orvar Lofgren, who should be credited with a term combining imagination with engineering, "imagineering," which grasps much of the ways that new motorways are perceived by people. ${ }^{31}$

The United States, the land of expressways glorified by Jean Baudrillard's "America," ${ }^{2}$ road movies, and road fiction, provides us with an exceptional ethnography of "a place on the side of the road." ${ }^{33}$ Kathleen Stewart provides an existentialist-oriented ethnography of the ways that the American road registers in landscapes, bodily resonances, and materialities, as well as of the people on the side of the road who are excluded from this widespread "roadness" and high speeds, in the very heart of the West.

Last but not least, the Asia-Pacific region also has several road ethnographies. Trankell ${ }^{34}$ wrote about a road in Laos, and the modernization effects and expec-

25. Harvey and Knox, "The Enchantment of Infrastructure"; Kernaghan, "Furrows and Walls."

26. Joao Pina-Cabral, "Paved Roads and Enchanted Mooresses: The Perception of the Past among the Peasant Population of the Alto-Minho," Man 22 (1987): 715-735.

27. Sharon Roseman, "How We Built the Road: The Politics of Memory in Rural Galicia," American Ethnologist 23, no. 3 (1996): 836-860.

28. Tom Selwyn, "Landscapes of Separation: Reflections on the Symbolism of By-pass Roads in Palestine," in Contested landscapes, ed. Barbara Bender and Margot Winer (Oxford: Berg, 2001), 225-240.

29. Kimberely Coles, "Ambivalent Builders: Europeanization, the Production of Difference, and Internationals in Bosnia-Herzegovina," Political and Legal Anthropology Review 25, no. 1 (2002): 1-18.

30. Dimitris Dalakoglou, "An Anthropology of the Road" (Ph.D. diss., University College London, 2009); Dimitris Dalakoglou, The Road: An Ethnography of (Im)mobility, Space and Crossborder Infrastructures in the Balkans (Manchester: Manchester University Press, 2016); Dimitris Dalakoglou, "The Road: An Ethnography of the Albanian-Greek Cross-border Motorway," American Ethnologist 37, no. 1 (2010): 132-149; Dimitris Dalakoglou, "The Road from Capitalism to Capitalism': Infrastructures of (Post) Socialism in Albania," Mobilities 7, no. 4 (2012): 571-586.

31. Orvar Löfgren, "Concrete Transnationalism? Bridge Building in the New Economy," Focaal 43 (2004): 59-76.

32. Jean Baudrillard, America (London: Verso, 1970).

33. Kathleen Stewart, A Place at the Side of the Road (Princeton, NJ: Princeton University Press, 1996).

34. Ing-Britt Trankell, On the Road in Laos: An Anthropological Study of Road Construction and Rural Communities (Uppsala: Uppsala Research Reports in Cultural Anthropology, 1993). 
tations that come together with the infrastructure; the roads in the highlands of Papua New Guinea, and the danger and violence along the roadscapes of the island, have inspired many anthropological works. ${ }^{35}$ Pedersen and Bunkenborg approach Sino-Mongolian cross-border roads as a technology of distanciation between Mongolians and Chinese on the local level, rather than a technology of connection. ${ }^{36}$ Roads and their material and social biography in Mongolia have also been approached by other anthropologists, producing insights on what a road is and what it is not. ${ }^{37}$

Although this list is not exhaustive, it is indicative of anthropology's current approach to studying roads. Back in 2008 it felt necessary for someone studying roads ethnographically to stress the need for roads-and infrastructure generally-to become an autonomous anthropological and ethnographic subject, and not a secondary issue analyzed in reference to other more "anthropological" themes. ${ }^{38}$ Today this statement sounds banal, as anthropologists have made an explicit turn toward infrastructural formations and a number of ethnographies of roads exist. Thus, the question that needs to preoccupy us when shaping an anthropological "dromology" is not how roads will come to the foreground of ethnographic research, but how we can understand anew established anthropological categories of study and analysis (e.g., the house, kinship, migration, technology, imagination, etc.) in reference to the road and vice versa. As anthropologists investigate these questions, we would do well to more thoroughly engage with the works beyond our discipline in order to refine our questions and test our methods.

Dimitris Dalakoglou is a professor at Vrije University, Amsterdam where he holds the Chair in Social Anthropology. He has studied ethnographic infrastructures since 2004, his most recent book is The Road: An Ethnography of (Im)mobility, Space and Cross-border Infrastructures in the Balkans (Manchester University Press, 2016).

35. David Hayano, Road through the Rainforest: Living Anthropology in Papua New Guinea (Prospect Heights, IL: Waveland Press, 1990); Michael O'Hanlon and Linda Frankland, "Co-present Landscapes: Routes and Rootedness as Sources of Identity in Highland New Guinea," in Landscape, Memory and History: Anthropological Perspectives, ed. Pamela Stewart and Andrew Strathern (London: Pluto Press, 2003), 166-188; Pamela Stewart and Andrew Strathern, "Death on the Move: Landscape, Violence on the Highlands Highway, Papua New Guinea," Anthropology \& Humanism 24, no. 1 (1999): 20-31.

36. Morten Pedersen and Mikkel Bunkenborg, "Roads that Separate," Mobilities 7, no. 4 (2012): 555-569.

37. Tanya Argounova-Low, "Roads and Roadlessness: Driving Trucks in Siberia," Journal of Ethnology and Folkloristics 6, no. 1 (2012): 71-88.

38. Dalakoglou, "An Anthropology of the Road"; Dalakoglou, The Road. 